\title{
The relationship between servant leadership, affective team commitment and team effectiveness
}

\author{
Authors: \\ Bright Mahembe ${ }^{1}$ \\ Amos S. Engelbrecht ${ }^{1}$ \\ Affiliations: \\ ${ }^{1}$ Department of Industrial \\ Psychology, Stellenbosch \\ University, South Africa \\ Correspondence to: \\ Bright Mahembe \\ Email: \\ bmahembe@sun.ac.za \\ Postal address: \\ Department of Industrial \\ Psychology, Stellenbosch \\ University, Private Bag X1, \\ Matieland 7602, South Africa \\ Dates: \\ Received: 14 Sept. 2012 \\ Accepted: 19 Dec. 2012 \\ Published: 10 Apr. 2013 \\ How to cite this article: \\ Mahembe, B., \& Engelbrecht, \\ A.S. (2013). The relationship \\ between servant leadership, \\ affective team commitment \\ and team effectiveness. SA \\ Journal of Human Resource \\ Management/SA Tydskrif vir \\ Menslikehulpbronbestuur, \\ 11(1), Art. \#495, 10 pages. \\ http://dx.doi.org/10.4102/ \\ sajhrm.v11i1.495

\section{Copyright: \\ (C) 2013. The Authors. Licensee: AOSIS OpenJournals. This work is licensed under the Creative Commons Attribution License.}

Read online:

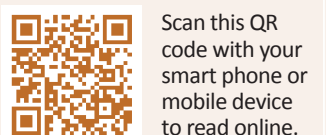

Orientation: Value-based leadership practices play a critical role in teamwork in highperformance organisations.

Research purpose: The aim of the study was to empirically validate a theoretical model explicating the structural relationships between servant leadership, affective team commitment and team effectiveness.

Motivation for the study: The increased reliance on teams for production calls for an analysis of the role of follower-focused leadership practices in enhancing team effectiveness.

Research design, approach and method: A non-probability and multicultural sample consisting of 202 primary and secondary school teachers was drawn from 32 schools in the Western Cape Province of South Africa.

Main findings: High levels of reliability were found and uni-dimensionality of the subscales was demonstrated through exploratory factor analyses. Good fit with the data was found for the measurement models through confirmatory factor analyses. Structural equation modelling showed a reasonable fit for the structural model. Positive relationships were found amongst servant leadership, team effectiveness and affective team commitment. Standard multiple regression analysis showed that affective team commitment moderated the relationship between servant leadership and team effectiveness.

Practical/managerial implications: The findings emphasise the central role played by servant leadership and affective team commitment in team performance. Servant leadership fosters team effectiveness if employees feel committed to their work team.

Contribution/value-add: The servant leadership style alone may not be a sufficient condition for team effectiveness; other variables, such as affective team commitment, also play a role. The study suggested specific variables that may also combine with leadership to positively influence team effectiveness.

\section{Introduction}

Effective teamwork has been identified by researchers as one of the core features of highperformance organisations (Afolabi, Adesina \& Aigbedion, 2009; Schlechter \& Strauss, 2008; Sheng \& Tian, 2010). Team-based approaches to work can, (1) increase innovation, (2) improve quality, productivity, organisational responsiveness and flexibility, (3) serve customers better and (4) reduce the time it takes for an organisation to transform an idea into a product that is viable and profitable within the marketplace (Glassop, 2002; Hamilton, Nickerson \& Owan, 2003). Given the pivotal role of teams in organisational success, team performance needs to be proactively managed to influence team effectiveness. Teamwork, facilitated by effective leadership, is one of the means used by organisations to increase productivity (Chen, Kirkman, Kanfer, Allen \& Rosen, 2007; Eisenbeiss, Van Knippenberg \& Boerner, 2008; Morgeson, DeRue \& Karam, 2010; Schaubroeck, Lam \& Cha, 2007; Transcritti, 2010). Whilst a leader is expected to be accountable for the effectiveness of his or her team, a service-oriented approach to leadership appears to be one of the important determinants of team effectiveness (Irving \& Longbotham, 2007).

Servant leadership comprises an understanding and practice of leadership that places the good of those who are led above the self-interest of the leader. A servant leader has true commitment to his or her followers and predominantly serves the needs of followers, hence providing vision and empowerment, with service being the main activity of the servant leader (Sendjaya \& Sarros, 2002; Spears, 2010). Servant leadership therefore has some important implications for team commitment (Dannhauser, 2007).

Whilst influence is generally 'considered the key element of leadership, servant leadership changes the focus of this influence by emphasizing the ideal of service in the leader-follower relationship' 
(Van Dierendonck, 2011, p. 1229). As 'servant leadership is demonstrated by empowering and developing people; by expressing humility, authenticity, interpersonal acceptance and stewardship; and by providing direction', followers are likely to feel empowered (Van Dierendonck, 2011, p. 1254). Prior research has demonstrated that followers who are empowered display more commitment; when employees are empowered, they portray a greater level of self-confidence and have a greater sense of being able to influence their work environment in a positive way (Zhu, May \& Avolio, 2004).

Whilst the literature on servant leadership and teams is increasing, paucity in research exists in South Africa on the relationships between servant leadership, affective team commitment and team effectiveness. It is also important to note that most of the studies on team effectiveness were carried out in business or revenue generating settings (Afolabi et al., 2009; Dannhauser, 2007), whilst a few studies were undertaken in service-oriented contexts such as educational settings (Bowman, 2005; DuFour, 2001). It is essential to understand team effectiveness in educational settings as it helps to shed some light on the nature of the school as a workplace, as well as on how the quality of interactions in schools affect teachers' performance. In a school workplace where there is interaction of a high quality amongst members, teachers will commit themselves to work harder and make their work experience more meaningful (Turan, 2002). According to DuFour (2001), principals who are inspired by the servant leadership role focus on developing a school climate and culture in which teachers share a common vision and a collective commitment to the team or school. School principals identified as servant leaders were rated highly by their teachers, compared to other school principals who use other leadership styles (Taylor, Martin, Hutchinson \& Jinks, 2007). When the school principal (servant leader) has served the teachers' (followers') needs through the provision of a clear vision and guidance, teachers, in turn, are likely to act as servant leaders or trail blazers for students by removing obstacles that stand in students' paths (Bowman, 2005).

\section{Aim of study}

Servant leadership and team commitment play a central role in team performance. The primary goal of the study was to conduct an analysis of the relationships between servant leadership, affective team commitment and team effectiveness. The secondary goal was to validate a theoretical model explicating the structural relationships between these variables in the South African education sector.

\section{Conceptualising team effectiveness}

It is necessary for organisations to have a clear and thorough understanding of what is meant by team effectiveness in order to utilise teams and enhance the overall success of the organisation (Hackman, 2002; Irving \& Longbotham, 2007; Piccoli, Powell \& Ives, 2004; Pina, Martinez \& Martinez, 2008; Ross, Jones \& Adams, 2008).

Owing to the complex nature of human behaviour, which is a fundamental part of teamwork, researchers have experienced multiple problems in defining the boundaries of team effectiveness and operationalising this construct (Pina et al., 2008). According to the literature, one can distinguish between two types of models regarding team effectiveness. The first is a uni-dimensional model that uses objective measures of team performance, or the degree of real productivity. The second type is multidimensional and is based on the assumption that team effectiveness depends on several other variables apart from performance or productivity (Pina et al., 2008).

Ross et al. (2008) defined team effectiveness by evaluating five broad principles contributing to team effectiveness. These principle variables used to evaluate team effectiveness were: performance, behaviour, attitude, team member style and corporate culture. Performance comprises the extent to which the output conforms to the customer's standard of quality, quantity, and timeliness. To ensure and increase team performance, there should be a compelling direction for the team's work. Compelling direction refers to whether the team has clear, challenging and consequential goals that focus on the outcomes to be accomplished (Hackman, 2002).

Behaviour refers to the way in which team members act and react to one another and circumstances, as well as perceived behavioural control (Ross et al., 2008). Attitude concerns team members' feelings of psychological safety, willingness to cooperate, reception and giving of feedback, and accepting responsibility. Team members' individual characteristics (e.g. assertiveness and responsiveness) also affect the effectiveness of the team as a whole. Lastly, corporate culture refers to the business climate in which the team operates, which has a significant influence that can either enhance or diminish team effectiveness (Ross et al., 2008). A supporting organisational culture refers to whether the team receives adequate resources, rewards, information, training, intergroup cooperation and support needed by team members (Hackman, 2002).

Team effectiveness is defined broadly as group-produced outputs and in terms of the consequences that the team has for its members (Piccoli et al., 2004). Irving and Longbotham (2007) have defined team effectiveness as the attainment of common objectives or goals through the coordination of team members' activities. Piccoli et al. (2004) further explained that for teams to be classified as effective, they need to produce high quality and levels of outputs in the form of goods and services. Team members should also find the working experience satisfactory. Thus, team effectiveness should measure the output of teams, the state of the group as a performing unit, as well as the impact of the group on its individual members.

\section{Conceptualising servant leadership}

Servant leadership is not a new concept; it can be traced back to the practice of leaders such as Mahatma Gandhi, Martin Luther King Jr and Mother Theresa, who promoted it as being the way to approach leadership (Sendjaya \& Sarros, 2002). 
The concept re-emerged in academic literature with the work of Robert Greenleaf, who coined the term 'servant leadership' more than 30 years ago (Dannhauser, 2007). Greenleaf's thoughts on leadership inspired a new way of thinking for many prominent leadership writers and thinkers. Despite initial lack of support for the concept - largely because of perceived paradoxes in, and misunderstandings of, the terminology - servant leadership has gained support and momentum, as evidenced by the ever-increasing number of scholarly articles on servant leadership (Sendjaya \& Sarros, 2002; Van Dierendonck, 2011).

Servant leadership is virtuous, highly ethical and based on the premise that service to followers is at the heart of leadership (Sendjaya, Sarros \& Santora, 2008). Servant leaders also demonstrate the qualities of vision, caring for other people, altruism, humility, hope, integrity, trustworthiness and interpersonal acceptance (Van Dierendonck, 2011). It can be deduced from the different conceptualisations of servant leadership that service to followers and valuing followers are the basic tenets of a servant leader. If team members perceive that their leader really cares about their wellness, they will become more committed to their teams.

\section{Conceptualising affective team commitment}

With Allen and Meyer's (1990) three-dimensional conceptualisation of organisational commitment adapted to team commitment, the dimensions of team commitment can be identified as, (1) affective commitment, which refers to an employee's emotional attachment to, identification with, and involvement in, the team, (2) continuance commitment, which indicates commitment based on the costs that an employee associates with leaving the team and (3) normative commitment, which refers to an employee's feelings of obligation to remain with the team. Employees with strong affective commitment remain because they want to, compared to those with strong continuance commitment who remain because they need to; those with strong normative commitment remain because they ought to do so (Allen \& Meyer, 1990, p. 3). Of these three components of organisational commitment, affective commitment has been the most widely studied (Bishop, Scott, Goldsby \& Cropanzano, 2005; Sheng \& Tian, 2010; Wasti, 2003) as it has consistent relationships with performance, attendance and intention to quit (Afolabi et al., 2009; Ferreira, 2012; Hammond, 2008; Oehley, 2007). As this study focuses on the impact of servant leadership on team effectiveness, affective commitment appears to be the most appropriate component of team commitment for predictive purposes.

\section{The relationships between servant leadership, affective team commitment and team effectiveness}

Organisations have a need for leadership styles that create favourable environments for teams to function optimally. Morgeson et al. (2010) viewed team leadership as a fundamental process, oriented around the satisfaction of critical team needs with the goal of enhancing team effectiveness. Clear communication of the team's mission and goals with proper feedback enhances cohesive relationships amongst team members and has a positive effect on the overall performance of teams. Setting challenging goals and clear performance expectations is the most important leadership function for facilitating effective team performance. Team leaders have to acquire the necessary resources to complete team goals, encourage team members to act autonomously and create a positive social climate within the team (Morgeson et al., 2010). It is thus evident that leadership is an essential part of team performance and contributes to team effectiveness through a variety of means.

Servant leadership distinctively specifies the combined motivation to be a leader with the need to serve as the foundation of a leader's behaviour. A team leader needs to be goal-directed, be able to handle different personality types within the team, create commitment, give recognition and enhance cohesiveness amongst team members. All of these aspects are incorporated in servant leadership (Van Dierendonck, 2011). Servant leadership is concerned about followers and creates conditions that enhance followers' wellbeing, thereby facilitating a shared vision (Van Dierendonck, 2011). Servant leadership adds the component of social responsibility to serve other people to leadership behaviour, as well as dedication to followers' needs and interests as opposed to their own (Sendjaya \& Sarros, 2002). Servant leaders focus on follower outcomes in terms of personal growth and development (Van Dierendonck, 2011). All these qualities would further contribute to a positive team climate.

The inspirational and moral component of servant leadership is important for the development of teams. Team members are more likely to work collaboratively in the achievement of organisational goals if they have inspirational and moral confidence in their leader (Van Dierendonck, 2011). Although numerous studies on the importance of leadership in team performance are available (Gupta, Huang \& Niranjan, 2010; Kuo, 2004; Morgeson et al., 2010), the role that servant leadership plays in the effective functioning of teams has not been studied extensively. In this regard, Dannhauser (2007) could not identify a significant relationship between servant leadership and team effectiveness in the South African automobile industry. Irving and Longbotham (2007) examined the relationship between servant leadership and team effectiveness in the US division of an international non-profit organisation, reporting a significant positive relationship between the two constructs. A study conducted by Hu and Liden (2011) also provided support for the existence of a positive relationship between servant leadership and team effectiveness. These findings were further confirmed by Transcritti (2010) in a recent study of church pastors in the US state of Ohio. On the basis of the above theoretical arguments and empirical findings, it was postulated that servant leadership has a positive effect on team effectiveness.

Little is known about the relationship between servant leadership and team commitment. Servant leadership can help organisations discover how to maximise their team 
performance by increasing resilience and productive time, whilst, at the same time, minimising negative factors such as exhaustion and absenteeism. When individuals feel cared for they will respond with greater loyalty towards their leader, feel compelled to generate solutions and commit to team and organisational goals (Ostrem, 2006).

In investigating the respective relationships between servant leadership, follower trust and team commitment within the South African context, Dannhauser (2007) revealed a significant positive relationship between servant leadership and team commitment. This result concurs with findings at the individual level of analysis, in which the perceived support of the leader has been documented to correlate positively with employees' commitment to the organisation (Bagraim, 2003; Boshoff, Van Wyk, Hoole \& Owen, 2002). As affective commitment appears to be the most widely used component of commitment for predictive purposes, it can therefore be inferred that fostering affective team commitment through servant leadership is likely to contribute to team effectiveness. Based on the above arguments and findings, it was postulated that servant leadership has a positive impact on affective team commitment.

Teams owe part of their success to the strength of bonds linking group members with one another, such as team identification and cohesion, coupled with honest communication, strong team commitment to the shared task and a willingness to put the needs of the team before individual interests (Forsyth, 2010). Members of cohesive teams are committed to their teams, with team commitment being indicated by the degree of attachment to the team, a long-term orientation to the team and intentions to remain within the group (Arriaga \& Agnew, 2001; Forsyth, 2010). As team cohesion and team member identification increases, so does team commitment (Johnson \& Johnson, 2006). More specifically, leaders develop affective commitment, which represents the extent to which members become identified with, emotionally attached to, and involved with the team and other members. Given that affective commitment has been documented as consistently linked to performance, it is expected that it will foster team effectiveness. Hammond (2008) has confirmed a positive relationship between affective team commitment and team effectiveness on a sample made up of participants from 44 engineering, manufacturing and sustainment teams within one of the largest companies in the USA. Based on the arguments presented above, it was postulated that affective team commitment, in turn, has a positive influence on team effectiveness.

\section{Theoretical model}

After an in-depth investigation of the literature, a conceptual model was derived. Figure 1 illustrates the conceptual model that depicts the specific hypothesised causal linkages between servant leadership, affective team commitment and team effectiveness.

\section{Statistical hypotheses}

The overarching research hypothesis for the close fit null hypothesis is:

$\mathrm{H}_{01}:$ RMSEA $<0.05$

$\mathrm{H}_{\mathrm{a} 1}:$ RMSEA $>0.05$

Where RMSEA is the root mean square error of approximation.

In order to test the validity of the proposed relationships in the structural model, the following specific research hypotheses were tested:

- Hypothesis 1: A significant positive relationship exists between servant leadership $\left(\xi_{1}\right)$ and team effectiveness $\left(\eta_{2}\right)\left(H_{02:} \gamma_{21}=0 ; H_{a 2:} \gamma_{21}>0\right)$.

- Hypothesis 2: A significant positive relationship exists between servant leadership $\left(\xi_{1}\right)$ and affective team commitment $\left(\eta_{1}\right)\left(\mathrm{H}_{03:} \gamma_{11}=0 ; \mathrm{H}_{\mathrm{a3}} \gamma_{11}>0\right)$.

- Hypothesis 3: A significant positive relationship exists between affective team commitment $\left(\eta_{1}\right)$ and team effectiveness $\left(\eta_{2}\right)\left(H_{04} \beta_{21}=0 ; H_{a 4:} \beta_{21}>0\right)$.

\section{Research design Research approach}

The objectives set out for this research were achieved through the use of a cross-sectional correlational research design. A quantitative survey design was used to achieve the research objective.

\section{Research method}

\section{Research participants}

Although the team is expected to be the unit of analysis in studies of this nature, the present study used the individual team members as the unit of analysis; hence, the hypotheses that have been discussed indicate team members' perceptions of the different relationships. A non-probability sampling strategy was used in the study. The study was conducted using primary and secondary school teachers from 32 schools in the Western Cape Province of South Africa. Out of the 400 questionnaires distributed to the members of the teams, 202 completed questionnaires were returned, yielding a response rate of $50.5 \%$.

The sample consisted of 137 female (68.2\%) and 64 male $(31.8 \%)$ employees. The majority $(60.2 \%)$ fell in the age category between 30 and 50 years. The ethnic distribution in the sample was: Black respondents $(24.9 \%)$, Coloured respondents $(56.2 \%)$ and White respondents (18.9\%). The

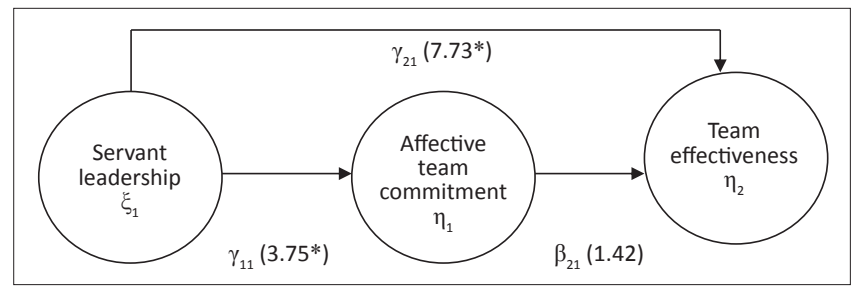

$*, t$-values $\geq|1.96|$ indicate signifiant path coefficients $(p<0.05)$.

FIGURE 1: The conceptual structural model. 
home language of the majority was Afrikaans (73.6\%), with a minority speaking their home languages in Xhosa (18.4\%) and English (5.0\%). Regarding their highest level of qualification, the majority of respondents had a degree or diploma (93.0\%).

\section{Measuring instruments}

Various self-reporting measuring instruments were identified and used in measuring the constructs under study such as the servant leadership questionnaire, an adapted team commitment survey and an adapted team effectiveness questionnaire, details of which are provided below.

Servant leadership: Servant leadership was measured using the servant leadership questionnaire (SLQ) (Barbuto \& Wheeler, 2006). The SLQ was formulated in an attempt to develop a scale that captures the 11 characteristics of servant leadership. Barbuto and Wheeler (2006), through factor analysis, found only five factors underlying 23 items. Reliabilities for the self and rater versions of the scale ranged from 0.68 to 0.87 and 0.82 to 0.92 , respectively. The rater version of the scale yielded the following coefficient alphas: altruistic calling ( $\alpha=0.82)$, emotional healing ( $\alpha=$ $0.91)$, wisdom $(\alpha=0.92)$, persuasive mapping $(\alpha=0.83)$ and organisational stewardship ( $\alpha=0.83$ ) (Barbuto \& Wheeler, 2006). Example items included: 'this person goes above and beyond the call of duty to meet my needs' (altruistic calling), 'this person is talented at helping me to heal emotionally' (emotional healing), 'this person is good at anticipating the consequences of decisions' (wisdom), 'this person is very persuasive' (persuasive mapping) and 'this person believes that the organisation needs to play a moral role in society' (organisational stewardship).

Affective team commitment: Team commitment was assessed using a six-item affective team commitment subscale adapted from the team commitment survey (TCS) developed by Bennet and Durkin (2000). The TCS is a modification of Allen and Meyer's (1990) organisational commitment scale in which the referent of commitment is changed from the organisation to the team, as suggested by Becker and Billing (1993). A high internal reliability coefficient was found for the affective commitment scale $(\alpha=0.98)$. Example affective team commitment scale items included: 'this team has great personal meaning for me'.

Team effectiveness questionnaire: An adapted 11-item team effectiveness questionnaire (TEQ) developed by Larson and LaFasto (2001) was used to measure team effectiveness. The TEQ is a self-reporting scale and is based on Larson and LaFasto's (2001) earlier grounded theory work that attempted to identify the essential characteristics of effective teams. The Cronbach alpha coefficient for this questionnaire is 0.85, which also was found when Dannhauser (2007) administered the TEQ on a South African sample. Example items included: 'achieving the team goal is a higher priority than any individual objective' and 'the team is given the resources it needs to get the job done'.

\section{Research procedure}

Access to the sample was achieved through personal delivery of the questionnaires to the various schools. The participants received a composite questionnaire including a covering letter, a biographical section and the three measuring instruments. The covering letter gave the rationale for the study and instructions on completing the questionnaires, as well as the participants' ethical rights.

\section{Statistical analysis}

Missing values: The missing values problem is a common occurrence when self-reporting instruments are used. In the present study, this problem was addressed through imputation by matching (Jöreskog \& Sörbom, 2006). Through this technique, missing values are substituted by values derived from one or more other cases that had a similar response pattern over a set of matching variables (Jöreskog \& Sörbom, 2006).

Structural equation modelling: Structural equation modelling (SEM) helps to explain the patterns of covariances found amongst the observed variables in terms of the relationships hypothesised by the measurement and structural models. The measurement model describes how each latent variable is operationalised by corresponding manifest indicators, whilst the structural model describes the relationships between the latent variables themselves (Diamantopoulos \& Siguaw, 2000).

Evaluating the measurement models: Item and exploratory factor analyses (EFA) were performed to identify any poor items (i.e. factor loadings $<0.30$; complex items) of the questionnaires used in the study using SPSS version 20.0 (2011). The application of the eigenvalues-greater-than-unit rule was used to identify the number of factors that underlie the observed correlation matrix for each of the subscales. EFA was also used to test for uni-dimensionality of the scales. After deletion of the poor items, LISREL version 8.80 (Jöreskog \& Sörbom, 2006) was used to perform confirmatory factor analyses (CFA) on the refined scales. Once a satisfactory fit was achieved, any item with an inadequate completely standardised factor loading $(<0.30)$ was deleted (Hair, Black, Babin, Anderson \& Tatham, 2006).

\section{Results}

\section{Missing values analysis}

The use of imputation by matching resulted in an effective sample size of 198 cases (Jöreskog \& Sörbom, 2006).

\section{Uni-dimensionality}

Based on item analysis and EFA, poor items were identified and excluded from the SLQ (1 item), TEQ (1 item) and affective TCS (3 items). Uni-dimensionality was confirmed on all the subscales.

\section{Goodness-of-fit: The measurement models}

Comparison of the goodness-of-fit (GFI) indices reported in Table 1 indicated that the refined structures of the SLQ, affective TCS and TEQ, presented a satisfactory fit with the data (Hair et al., 2006; Kelloway, 1998). In terms of the GFI indices, the $\chi^{2} / \mathrm{df}$ ratio $(2.45-4.85)$ for the refined 
measurement models fell in the 2-5 range that is indicative of acceptable fit (Kelloway, 1998). As recommended by Kelloway (1998), it is important not to rely solely on the $\chi^{2} / \mathrm{df}$ ratio, but to rather take into account a range of indices. The RMSEA indeed suggested that the refined measurement models fit the obtained data adequately $(0.04-0.08)$, as values $<0.08$ represent good model fit. The $p$-value for test of close fit (RMSEA < 0.05) varied between 0.06 and 0.51 ; the null hypothesis of close fit was therefore not rejected and the SLQ and TCS measurement models can be said to show close fit. However, the TEQ measurement model did not show close fit (0.01). The standardised root mean squared residual (RMR) values of $0.04-0.05$ are indicative of good model fit $(<0.05)$. The GFI values for the TEQ and TCS measurement models are close to $1.00(0.90-0.95)$, indicating that good fit has been achieved, as each scale has reached the $>0.90$ level required to indicate good fit. However, for the SLQ measurement model, the GFI value of 0.82 fell marginally below the good fit level.

The results of the incremental fit measures indicate that, when compared to a baseline model, all three refined measurement models achieved normed fit index (NFI), non-normed fit index (NNFI), comparative fit index (CFI), incremental fit index (IFI) and relative fit indices indices $>0.90$, which represents good fit (Hair et al., 2006; Kelloway, 1998). These relative indices therefore appear to portray a positive picture of model fit.

\section{Measurement models: Factor loadings}

Table 2 presents a summary of the factor loadings obtained for each of the refined measurement models. Except for one item, the completely standardised factor loading for each item comprising the measurement model exceeded the $>0.50$ level (Hair et al., 2006). This means that the items, in general, appeared to significantly reflect the dimension they were designed to represent.

\section{Item analysis}

Table 2 provides the reliability scores for each of the refined measuring scales. High levels of reliability were found for all subscales $(\alpha>0.70)$ (Nunnally, 1978). Satisfactory reliabilities were also found for the total SLQ $(\alpha=0.97)$, total TEQ $(\alpha=0.89)$ and the affective TCS $(\alpha=0.76)$.

\section{Goodness-of-fit indices for the structural model}

The LISREL program formally tests the null hypothesis of close fit $\left(\mathrm{H}_{0}\right.$ : RMSEA $\left.\leq 0.050\right)$. With the exceedance probability (0.032) being very small at the 0.050 level of significance, the close fit null hypothesis is rejected. The structural model therefore does not show close fit. However, after interpreting all other fit indices, the conclusion was reached that the structural model fitted the data reasonably well (see Table 1).

\section{The relationship between servant leadership and team effectiveness}

The purpose of evaluating the structural model through SEM is to determine whether the theoretical relationships specified at the conceptualisation stage are substantiated by the data. A positive relationship was found between servant leadership and team effectiveness $(t=7.73, p<0.05)$ (see Table 3). Thus, Hypothesis 1 was confirmed.

\section{The relationship between servant leadership and affective team commitment}

A positive relationship was found between servant leadership and affective team commitment $(t=3.75, p<0.05)$. Consequently, Hypothesis 2 was supported (see Table 3).

TABLE 1: Goodness-of-fit indices obtained for the refined servant leadership questionnaire, affective team commitment survey and team effectiveness questionnaire measurement and structural models.

\begin{tabular}{|c|c|c|c|c|c|c|c|c|c|c|}
\hline Model & $S-B \chi^{2} / d f$ & RMSEA & $p_{\text {close fit }}$ & SRMR & GFI & NFI & NNFI & CFI & IFI & RFI \\
\hline SLQ & 2.45 & 0.060 & 0.061 & 0.049 & 0.82 & 0.98 & 0.99 & 0.99 & 0.99 & 0.97 \\
\hline TCS & 4.85 & 0.039 & 0.510 & 0.041 & 0.95 & 0.99 & 0.99 & 0.99 & 0.99 & 0.98 \\
\hline TEQ & 3.20 & 0.083 & 0.010 & 0.050 & 0.90 & 0.96 & 0.97 & 0.98 & 0.98 & 0.95 \\
\hline SMODEL & 2.59 & 0.082 & 0.032 & 0.035 & 0.93 & 0.97 & 0.98 & 0.98 & 0.98 & 0.96 \\
\hline
\end{tabular}

S-B $\chi^{2}$, Sattora-Bentler scaled Chi-square; df, degrees of freedom; RMSEA, root mean square error of approximation; $p_{\text {close }}$ p-value for test of close fit (RMSEA < 0.05 ); SRMR, standardised root mean residual; GFI, goodness-of-fit index; NFI, normed fit index; NNFI, non-normed fit index; CFI, comparative fit index, IFI; incremental fit index; RFI, relative fit index; SLQ, servant leadership questionnaire; TCS, team commitment survey; TEQ, team effectiveness questionnaire; SMODEL, structural model.

TABLE 2: Refined measurement scales: Factor loadings and reliability

\begin{tabular}{|c|c|c|c|c|}
\hline Scale & Dimensions or subscales & No. of items & Factor loadings & Cronbach's alpha $(\alpha)$ \\
\hline \multirow[t]{5}{*}{ SLQ } & Altruistic calling & 4 & $0.78-0.91$ & 0.90 \\
\hline & Emotional healing & 4 & $0.74-0.90$ & 0.92 \\
\hline & Wisdom & 5 & $0.78-0.89$ & 0.92 \\
\hline & Persuasive mapping & 4 & $0.72-0.83$ & 0.87 \\
\hline & Organisational stewardship & 5 & $0.78-0.91$ & 0.93 \\
\hline Total SLQ & - & 22 & - & 0.97 \\
\hline \multirow[t]{2}{*}{ TEQ } & Team member effectiveness & 6 & $0.47-0.79$ & 0.80 \\
\hline & Team leader effectiveness & 4 & $0.80-0.86$ & 0.90 \\
\hline Total TEQ & - & 10 & - & 0.89 \\
\hline Affective TCS & - & 5 & $0.68-0.84$ & 0.76 \\
\hline
\end{tabular}

SLQ, servant leadership questionnaire; TEQ, team effectiveness questionnaire; TCS, team commitment survey. 


\section{The relationship between affective team commitment and team effectiveness}

The SEM path between affective team commitment and team effectiveness was found to be insignificant and Hypothesis 3 could thus be rejected $(t=1.42, p>0.05)$ (See Table 3 ). Consequently, the relationship between servant leadership and team effectiveness was further analysed to investigate whether this relationship may be moderated by affective team commitment.

\section{The moderating role of affective team commitment}

Standard multiple regression analysis showed that affective team commitment moderated the relationship between servant leadership and team effectiveness $(t=2.45, p<0.05)$ (see Table 4 and Figure 2). Both servant leadership (TOTSL) and the interaction effect variable (SL*TC) made a significant $(p<0.05)$ unique contribution in explaining team effectiveness $(F=98.305, p<0.001)$. The regression analysis results also showed low possibility of multicollinearity (tolerance value > 0.10) (Pallant, 2010) (see Table 4).

\section{Ethical considerations}

In terms of ethics, permission for the research was obtained from the institution's research ethics committee, as well as the Department of Education. Informed consent was sought from the participants before questionnaire completion and confidentiality of the information and data obtained was maintained.

\section{Trustworthiness \\ Reliability}

The reliability of each of the instruments used in the study was ensured through the use of the scale reliability analysis procedure available in SPSS (2011), as discussed in the 'Results' section. The use of instruments that have been proven to be reliable in previous research ensured success in ascertaining instrument reliability.

\section{Validity}

Validity was ensured through the use of appropriate and standardised measuring instruments. The construct validity of the instruments was ensured through the use of standard instruments and subjecting the instruments to confirmatory factor analysis.

\section{Discussion}

The aim of the study was to validate a theoretical model explicating the structural relationships between servant leadership, affective team commitment and team effectiveness. The specific objectives were to develop an explanatory structural model that explicates the manner in which servant leadership and affective team commitment affect team effectiveness, to test the model's fit with data and
TABLE 3: The gamma and beta matrix of path coefficients for the structural model.

\begin{tabular}{lll}
\hline Latent variable & Servant leadership & Team effectiveness \\
\hline Affective team commitment & $\mathbf{0 . 3 5}$ & $\mathbf{0 . 0 8}$ \\
& $(0.09)$ & $(0.06)$ \\
& 1.42 & $3.75^{*}$ \\
Team effectiveness & $\mathbf{0 . 7 7}$ & - \\
& $(0.10)$ & - \\
& $7.73^{*}$ & - \\
\hline
\end{tabular}

Completely standardised path coefficients in bold.

Standard error estimates in brackets

$t$-values $\geq|1.96|$ indicate significant parameter estimates

$*, p<0.05$

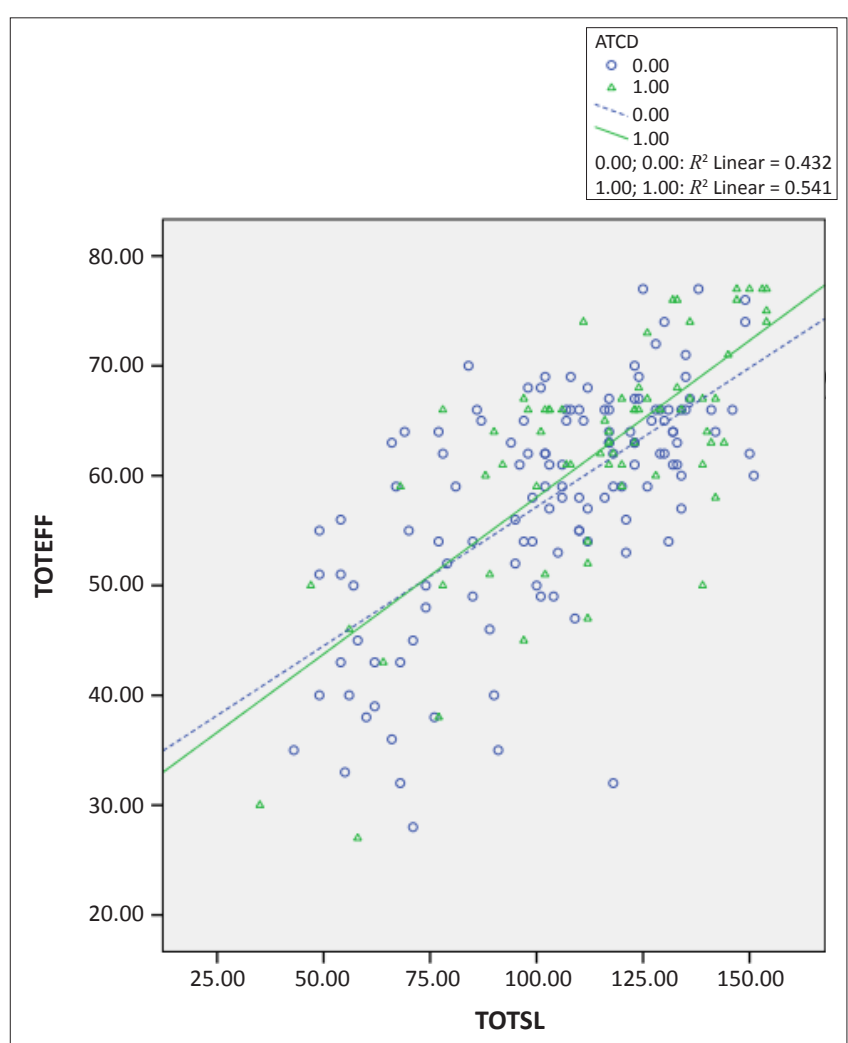

TOTEFF, team effectiveness total score; TOTSL, servant leadership total score; ATCD, affective team commitment dichotomised.

FIGURE 2: The scatter plot of the interaction effect of affective team commitment on servant leadership and team effectiveness.

to evaluate the significance of the hypothesised paths in the model. The potential contribution of the study relates to the central role played by servant leadership in influencing team behaviour.

With regard to the fit of the model, the GFI indices indicate that both the measurement and the structural models produced reasonable fit. The results imply that the items measured the dimensions (latent variables) as postulated, as well as supported the theoretical model underlying the postulated relationships between the latent variables.

Servant leadership was found to have a positive effect on team effectiveness. This finding is consistent with results obtained by $\mathrm{Hu}$ and Liden (2011), Irving and Longbotham (2007) and Transcritti (2010), which reported a positive relationship between servant leadership and team 
TABLE 4: Standard regression analysis: Testing moderating effect.

\begin{tabular}{|c|c|c|c|c|c|c|c|c|c|}
\hline \multirow[t]{2}{*}{ Variable or model } & \multicolumn{2}{|c|}{ Unstandardised coefficients } & \multirow{2}{*}{$\begin{array}{l}\text { Standardised } \\
\text { coefficients }(\beta)\end{array}$} & \multicolumn{6}{|c|}{ Collinearity statistics } \\
\hline & B & Standarderror & & $t$ & $p$ & $F$ & $\boldsymbol{R}$ & $R^{2}$ & Tolerance \\
\hline Constant & 29.451 & 2.016 & - & 14.608 & 0.000 & $98.305^{* *}$ & 0.709 & 0.502 & - \\
\hline TOTSL & 0.155 & 0.040 & $0.444 * *$ & 3.851 & 0.000 & - & - & - & 0.192 \\
\hline SL*TC & 0.003 & 0.001 & $0.283^{*}$ & 2.452 & 0.015 & - & - & - & 0.192 \\
\hline
\end{tabular}

$N=198$, sample size.

$\mathrm{B}$, unstandardised coefficient; $\beta$, beta; $t, t$-test; $p$, $p$-value (significance); $F, F$-test; $R$, multiple correlation coefficient; $R^{2}$, coefficient of determination; TOTSL, Servant leadership total score; SL*TC, interaction effect variable

effectiveness. However, this finding is not consistent with findings from Dannhauser (2007) on a South African sample. The differences can be explained in terms of the nature of the samples. Dannhauser's (2007) study was conducted on revenue-generating teams in the automobile industry, whilst the sample used in the present study was in the serviceoriented education sector.

A positive relationship was found between servant leadership and affective team commitment. These findings are consistent with the findings reported by Dannhauser (2007). The Dannhauser study used the three-component model of commitment (i.e. affective, normative and continuance), although the construct was collapsed to two factors in response to the exploratory factor analyses output for the team commitment scales used in the study.

According to the findings of the present study, there is no significant relationship between affective team commitment and team effectiveness. This contradicts the previous findings on the positive relationship between the two constructs (Hammond, 2008; Salas, Goodwin \& Burke, 2008). Affective team commitment might not have a direct influence on team effectiveness, but rather an indirect effect through moderators such as organisational trust, justice and organisational citizenship behaviour. The question also invariably arises as to the extent to which this result is caused by the inability to successfully operationalise the latent variable of team effectiveness. Although the present study failed to confirm a mediating effect of affective team commitment on the relationship between servant leadership and team effectiveness, affective team commitment has been found to be a significant moderating variable of this relationship. Hence, the ability of a servant leader to purposefully develop positive feelings of nurturance, service and employee empowerment should be powerful enough to appeal to the employees' feelings of identification with the team through enhanced affective team commitment in order to positively influence team effectiveness. In other words, the servant leader should relate with the employees in a way that enhances employees' attachment with the team for effective team functioning to occur (Hammond, 2008; Ostren, 2006).

\section{Limitations and suggestions for future research}

The use of the English language as the mode of communication posed a challenge, as some of the schools refused to participate because the language of the questionnaire went against their official language policy. Although the procedures involved in the translation of standard research instruments are cumbersome, future studies face the challenge of having to address the use of the participants' mother language in data collection.

Most of the participants were drawn from the African and Coloured ethnic groups ( $>80 \%$ ) and only a small proportion was White, which reduced the generalisability of the findings. The sample consisted only of teachers and so could be seen as being rather homogenous; therefore, more heterogeneous demographics should be represented in samples used in future studies.

Collecting research data at a single point in time rather than long-term and continued measurement (e.g. longitudinally over a period of time) may have exacerbated same-source or common method biases. Podsakoff and MacKenzie (1994) have posited that a longitudinal design could reduce this potential influence. They stated two further advantages that a longitudinal study would have over cross-sectional studies such as the one reported in this study. These include the following:

- It would permit better assessment of the causal priority of servant leadership, affective team commitment, and team effectiveness.

- It would allow examination of the longer-term effects of servant leadership and affective team commitment on team effectiveness.

Future research should consider the possibility of expanding the theoretical model by formally incorporating additional latent variables, such as cultural experiences, emotional intelligence, organisational justice, trust, empowerment and organisational citizenship behaviour, in an attempt to explain additional variance in team effectiveness. Furthermore, greater psychometric refining of the measuring instruments used in this study is required.

The study was conducted in an educational setting which is usually service oriented, whilst business settings are revenue generating. Future studies should therefore examine whether service-oriented and revenue teams are comparable. The treatment of each school as comprising a team had its own weakness. In larger schools, between 30 and 75 teachers may comprise various phases (foundation phase, intermediate phase and senior phase). The way these sub-teams function may be different from how the broader school team works; foundation phase teachers might work together much more efficiently than those in the intermediate phase. Furthermore, 
future studies should also consider using larger sample sizes to ensure that the eventual sample size is not smaller than 200 , which is the minimum sample size recommended when using SEM for testing hypothesised models.

\section{Managerial implications}

The current study reported positive relationships between servant leadership and affective team commitment, as well as team effectiveness. It was also found that affective team commitment is a significant moderator of the relationship between servant leadership and team effectiveness. On the basis of these results, management in organisations should focus on increasing team effectiveness through the development of empowering and people-oriented leadership styles such as servant leadership. Servant leadership is one of the value-based leadership styles that foster employee development and has a significant influence on team effectiveness when employees feel emotionally committed to their work teams.

\section{Conclusion}

Servant leadership incorporates the ideals of empowerment, team building, participatory management and the service ethic necessary for the promotion of team commitment and team effectiveness. This research has shown that the use of servant leadership and affective commitment has important implications for teambuilding interventions that can be used to assist work teams to become more effective.

\section{Acknowledgements Competing interests}

The authors declare that they have no financial or personal relationships which may have inappropriately influenced them in writing this article.

\section{Authors' contributions}

B.M. (Stellenbosch University) was the project leader responsible for the data collection, statistical analyses and write-up of the article, whilst A.S.E. (Stellenbosch University) contributed to the refinement of the measures, as well as the write-up of the article.

\section{References}

Afolabi, O.A., Adesina, A., \& Aigbedion, A. (2009). Influence of team leadership and team commitment on teamwork and conscientiousness. Journal of Social Sciences, 21(3), 211-216.

Allen, N.J., \& Meyer, J.P. (1990). The measurement and antecedents of affective, continuance and normative commitment to the organisation. Journal of Occupational Psychology, 63(1), 1-18. http://dx.doi. org/10.1111/j.2044-8325.1990.tb00506.x

Arriaga, X.B., \& Agnew, C.R. (2001). Being committed: Affective, cognitive, and conative components of relationship commitment. Personality and Social Psychology Bulletin, 27, 1190-1203. http://dx.doi.org/10.1177/0146167201279011

Bagraim, J.J. (2003). The nature and measurement of multiple commitment foci amongst South African knowledge workers. Management Dynamics, 12(2), 1323.

Barbuto, J.E., \& Wheeler, D.W. (2006). Scale development and construct clarification of servant leadership. Group and Organisational Management, 31(3), 300-326. http://dx.doi.org/10.1177/1059601106287091
Becker, T.E., \& Billings, R.S. (1993). Profiles of commitment: An empirical test. Journal of Organisational Behaviour, 14(2), 177-190. http://dx.doi.org/10.1002/ job.4030140207

Bennet, H., \& Durkin, M. (2000). The effects of organisational change on employee psychological attachment. Journal of Managerial Psychology, 15(2), 126-148. http://dx.doi.org/10.1108/02683940010310328

Bishop, J.W., Scott, K.D., Goldsby, M.G., \& Cropanzano, R. (2005). A construct validity study of commitment and perceived support variables. A multifoci approach across different team environments. Group \& Organisation Management, 30(2), 153-180. http://dx.doi.org/10.1177/1059601103255772

Boshoff, A.B., Van Wyk, R., Hoole, C., \& Owen, J.H. (2002). The prediction of intention to quit by means of biographic variables, work commitment, role strain and psychological climate. Management Dynamics, 11(4), 14-28.

Bowman, R.F. (2005). Teacher as servant leader. Clearing House, 78(6), 257-259. http://dx.doi.org/10.3200/TCHS.78.6.257-260

Chen, G., Kirkman, BL., Kanfer, R., Allen, D., \& Rosen, B. (2007). A multilevel study of leadership, empowerment, and performance in teams. Journal of Applied Psychology, 92(2), 331-346. http://dx.doi.org/10.1037/0021-9010.92.2.331, PMid:17371082

Dannhauser, Z. (2007). Relationship between servant leadership, follower trust, team commitment and unit effectiveness. Doctoral dissertation. Stellenbosch: team commitment and unit
University of Stellenbosch.

Diamantopoulos, A., \& Siguaw, J.A. (2000). Introducing LISREL. London: Sage.

DuFour, R. (2001). In the right context. Journal of Staff Development, 22(1), 14-17.

Eisenbeiss, S.A., Van Knippenberg, D., \& Boerner, S. (2008). Transformational leadership and team innovation: Integrating team climate principles. Journal of Applied Psychology, 93(6), 1438-1446. http://dx.doi.org/10.1037/a0012716, PMid:19025260

Ferreira, N. (2012). Hardiness in relation to organisational commitment in the human resource management field. SA Journal of Human Resource Management, 10(2), 1-10. http://dx.doi.org/10.4102/sajhrm.v10i2.418

Forsyth, D.R. (2010). Group dynamics. (5th edn.). Wadsworth: Cengage Learning.

Glassop, L. (2002). The organisational benefits of teams. Human Relations, 55(2), 225-249. http://dx.doi.org/10.1177/0018726702055002184

Gupta, V.K., Huang, R., \& Niranjan, S. (2010). A longitudinal examination of the relationship between team leadership and performance. Journa of Leadership \& Organisational Studies, 17(4), 335-350. http://dx.doi. org/10.1177/1548051809359184

Hackman, J.R. (2002). Leading teams: Setting the stage for great performances. Boston: Harvard Business School Press.

Hair, J.F., Black, W.C., Babin, B.J., Anderson, R.E., \& Tatham, R.L. (2006). Multivariate data analysis. (6th edn). Upper Saddle River: Prentice Hall.

Hamilton, B.H., Nickerson, J.A., \& Owan, H. (2003). Team incentives and worker heterogeneity: An empirical analysis of the impact of teams on productivity and participation. The Journal of Political Economy, 111(3), 465-497. http://dx.doi. participation. The Journ
org/10.1086/374182

Hammond, H.R. (2008). The antecedents of affective commitment to the team and their impact on team effectiveness. Unpublished doctoral thesis, TUI University, Cyprus, California.

Hu, J., \& Liden, R.C. (2011). Antecedents of team potency and team effectiveness: An examination of goal and process clarity and servant leadership. Journal of Applied Psychology, 96(4), 851-862. http://dx.doi.org/10.1037/a0022465, PMid:21319877

Irving, J.A., \& Longbotham, G.J. (2007). Team effectiveness and six essential servant leadership themes: A regression model based on items in the organizational leadership assessment. International Journal of Leadership Studies, 2(2), 98-113.

Johnson, D.W., \& Johnson, F.P. (2006). Joining together: Group theory and group skills. (9th edn.). New York: Pearson International.

Jöreskog, K.G., \& Sörbom, D. (2006). Interactive LISREL 8.80. Chicago: Scientific Software International.

Kelloway, E.K. (1998). Using LISREL for structural equation modelling: A researcher's guide. Thousand Oaks: SAGE. PMid:9520604

Kuo, C.C. (2004). Research on impacts of team leadership on team effectiveness. Journal of American Academy of Business, 5(1), 266-277.

Larson, C.E., \& LaFasto, F.M.J. (2001). The team effectiveness questionnaire. In P.G. Northouse (Ed.), Leadership: Theory and practice. (2nd edn.). (p. 184). Thousand Oaks: SAGE.

Morgeson, F.P., DeRue, D.S., \& Karam, E.P. (2010). Leadership in teams: A functional approach to understanding leadership structures and processes. Journal of Management, 36(1), 5-39. http://dx.doi.org/10.1177/0149206309347376

Nunnally, J.C. (1978). Psychometric theory. New York: McGraw-Hill.

Oehley, A. (2007). The development and evaluation of a partial talent management competence model. Masters thesis. Stellenbosch: University of Stellenbosch.

Ostrem, L.M. (2006). Servant leadership and work-related outcomes: A multilevel model. PhD thesis. Lincoln: University of Nebraska.

Pallant, J. (2010). SPSS survival manual: A step by step guide to data analysis using SPSS. (4th edn.). London: McGraw-Hill.

Piccoli, G., Powell, A., \& Ives, B. (2004). Virtual teams: Team control structure, work processes, and team effectiveness. Information Technology \& People, 17(4), 359379. http://dx.doi.org/10.1108/09593840410570258 
Pina, M., Martinez, A., \& Martinez, L. (2008). Teams in organizations: A review on team effectiveness. Team Performance Management, 14(1/2), 7-21. http:// dx.doi.org/10.1108/13527590810860177

Podsakoff, P.M., \& Mackenzie, S.B. (1994). An examination of the psychometric properties and nomological validity of some revised and reduced 'substitutes for leadership' scales. Journal of Applied Psychology, 79(5), 702-713. http://dx.doi. org/10.1037/0021-9010.79.5.702

Ross, T.M., Jones, E.C., \& Adams, S.G. (2008). Can team effectiveness be predicted? Team Perfomance Management, 14(5/6), 248-268. http://dx.doi. org/10.1108/13527590810898518

Salas, E., Goodwin, G.F., \& Burke, C.S. (2008). Team effectiveness in complex organisations: Cross-disciplinary perspectives and approaches. Mahwah Lawrence Erlbaum.

Schaubroeck, J., Lam, S.S.K., \& Cha, S.E. (2007). Embracing transformational leadership: Team values and the impact of leader behaviour on team performance. Journal of Applied Psychology, 92, 1020-1030. http://dx.doi.org/10.1037/0021 9010.92.4.1020, PMid:17638462

Schlechter, A.F., \& Strauss, J.J. (2008). Leader emotional intelligence, transformational leadership, trust and team commitment: Testing a model within a team context. South African Journal of Industrial Psychology, 34(1), 42-53.

Sendjaya, S., \& Sarros, J.C. (2002). Servant leadership: Its origin, development, and application in organisations. Journal of Leadership \& Organisational Studies, 9(2), 57-65. http://dx.doi.org/10.1177/107179190200900205

Sendjaya, S., Sarros, J.C., \& Santora, J.C. (2008). Defining and measuring servan leadership behaviour in organisations. Journal of Management Studies, 45(2) 402-424. http://dx.doi.org/10.1111/j.1467-6486.2007.00761.x
Sheng, C., \& Tian, Y. (2010). Relationships among teamwork behaviour, trust, perceived team support, and team commitment. Social Behaviour and Personality, 38(10), 1297-1306. http://dx.doi.org/10.2224/sbp.2010.38.10.1297

Spears, L.C. (2010). The character and servant leadership: Ten characteristics of effective, caring leaders. Journal of Virtues \& Leadership, 1(1), 25-30.

SPSS 20.0 for Windows [Computer software] (2011). Chicago: Scientific Software International.

Taylor, T., Martin, B.N., Hutchinson, S., \& Jinks, M. (2007). Examination of leadership practices of principals identified as servant leaders. International Journal of Leadership in Education, 10(4), 401-419. http://dx.doi. org/10.1080/13603120701408262

Transcritti, F.G. (2010). The relationship between servant leadership and team effectiveness of deacon ministries in Southern Baptist churches. Unpublished PhD thesis. The Southern Baptist Theological Seminary, Louisville, Kentucky.

Turan, S. (2002). Organisational climate and organisational commitment: A study of human interactions in Turkish public schools. Educational Planning, 14(2), 20-30.

Van Dierendonck, D. (2011). Servant leadership: A review and synthesis. Journal of Management, 37(4), 1228-1261. http://dx.doi.org/10.1177/0149206310380462

Wasti, A.S. (2003). Organisational commitment, turnover intentions and the influence of cultural values. Journal of Occupational and Organisational Psychology, 76, 303-321. http://dx.doi.org/10.1348/096317903769647193

Zhu, W., May, D.R., \& Avolio, B.J. (2004). The impact of ethical leadership behaviour on employee outcomes: The roles of psychological empowerment and authenticity. Journal of Leadership \& Organisational Studies, 11(1), 16-26. http://dx.doi. org/10.1177/107179190401100104 